\title{
Neither Adopted nor Borrowed: A Critique of the Conception of the South African Bill of Rights
}

\section{P.ER}

Pioneer in peer-reviewed, open access online law publications

Author

Felix Dube

Affiliation

North-West University South Africa

Email Felix.Dube@nwu.ac.za

Date Submission

30 January 2020

Date Revised

13 July 2020

Date Accepted

13 July 2020

Date published

28 August 2020

Editor Prof A Agbor

How to cite this article

Dube F "Neither Adopted nor

Borrowed: A Critique of the

Conception of the South African Bill of Rights" PER / PELJ 2020(23) -

DOI

http://dx.doi.org/10.17159/1727-

3781/2020/v23i0a8794

Copyright

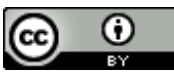

DOI

http://dx.doi.org/10.17159/1727-

3781/2020/v23i0a8794

\begin{abstract}
The failure of the post-apartheid government to deliver on some of the promises of the South African Bill of Rights, coupled with the appropriation of the Bill of Rights by the international human rights movement, create the impression that the Bill of Rights is a neo-liberal instrument which is irrelevant to the needs of South Africans and the realities of their circumstances. If the people of South Africa are convinced that the Bill of Rights embraces a Western agenda more than it expresses their collective aspirations, it will lose its legitimacy. While acknowledging that the conception of the Bill of Rights is contested between the international human rights movement and some South Africans, this article shows that the Bill of Rights was neither adopted nor borrowed from the international human rights movement. South Africans did not assimilate the International Bill of Rights but conceived their own Bill of Rights in the early decades of the $20^{\text {th }}$ Century. The conception of the South African Bill of Rights was a response to colonialism and apartheid and was not a consequence of tutelage by the international human rights movement.
\end{abstract}

\section{Keywords}

International human rights movement; International Bill of Rights; human rights discourse; Bill of Rights; South Africa. 


\section{Introduction}

The international human rights movement views the South African Bill of Rights as one of its most remarkable achievements. ${ }^{1}$ The desire of the international human rights movement to claim credit for progress in human rights in South Africa is not surprising, considering the strides made by the state in the protection, respect and promotion of human rights since the abolition of apartheid. The appropriation of the beautiful South African human rights story by the international human rights movement is motivated by four main reasons. First, the drafters of the South African Constitution ${ }^{2}$ borrowed from the text of the International Bill of Rights. ${ }^{3}$ Second, the drafters of the International Bill of Rights conceived the global human rights movement. ${ }^{4}$ The second reason clouds (and potentially distorts) scholarly understanding of the genesis of the South African human rights movement, particularly given the Western view that "human rights norms [are] antibiotics that must be administered to the sick, in this case the global South, even if they are unwilling to cooperate." ${ }^{15}$ Third, President Mandela signed the current South African Constitution on the anniversary of the adoption of the Universal Declaration of Human Rights (the UDHR) and thus inadvertently created the impression that South Africa adopted its Bill of

Felix Dube. LLB (Univen) LLM LLD (NWU). Postdoctoral fellow, Faculty of Law, NorthWest University, South Africa. Email: Felix.Dube@nwu.ac.za. ORCiD: https://orcid.org/0000-0002-6490-4629. The main aspects of this article were presented at a seminar on Perspectives on Managing Diversity, Inclusion and Tolerance in Pluralist Societies, organised by the Deanery of the Faculty of Law, North-West University, on 22 March 2018 as part of the year's Human Rights Day activities. The article was completed in 2019 with the financial generosity of the National Research Foundation (Grant no: 115581) through the South African Research Chair in Cities, Law and Environmental Sustainability (CLES) in the Faculty of Law, North-West University. My thanks go to Prof Anél du Plessis, Dr Brews Soyapi and my colleagues at CLES for their insightful comments on the draft manuscript. I am also grateful to the anonymous reviewers whose recommendations have been incorporated in the final manuscript.

1 Mutua 1997 Harv Hum Rts $J$ 63-64. For a definition of the international human rights movement, see Neier International Human Rights Movement 2 and Mutua 2001 Harv Int'I LJ 201.

2 Constitution of the Republic of South Africa, 1996 (the Constitution hereinafter).

3 Roberts Contentious History of the International Bill of Rights 2-3 argues that the International Bill of Rights is composed of the Universal Declaration of Human Rights (1948) (the UDHR hereinafter), the International Covenant on Civil and Political Rights (1966) (the ICCPR hereinafter), and the International Covenant on Economic, Social and Cultural Rights (1966) (the ICESCR hereinafter). Notably, the drafters of the South African Constitution drew some wisdom from the texts of the constitutions of liberal Western states such as Canada, Germany and the United States of America - see Davis 2003 ICON 187.

4 Mutua "Transformation of Africa" 906.

5 Mutua "Transformation of Africa" 911 (emphasis added) attributes the statement to Kenneth Roth, formerly the executive director of Human Rights Watch. 
Rights pursuant to the efforts of the international human rights movement. ${ }^{6}$ Fourth, some scholars ascribe the adoption of the Constitution and its Bill of Rights to globalisation, legal transplants of the $20^{\text {th }}$ Century, and the "third wave of democratisation".?

There is a need to set the record straight on the genesis of the South African Bill of Rights. The failure of the post-apartheid state to deliver on some of the most important promises of the Bill of Rights, coupled with the appropriation of the Bill of Rights by the international human rights movement, creates the impression that the Bill of Rights is Eurocentric and irrelevant to the needs of South Africans. ${ }^{8}$ If the people of South Africa are convinced that the Bill of Rights embraces a Western agenda more than it expresses their collective aspirations, then the Bill of Rights might as well lose its legitimacy, since often political and social realities, not formal legal criteria, validate the legitimacy of governments and legal systems. ${ }^{9}$

This article is structured as follows. The first section after this introduction contextualises the global human rights movement through the lenses of leading scholars on human rights discourse. The section briefly analyses the conception and birth of the International Bill of Rights from the UDHR in 1948 to show that South Africans were, to the least extent possible, unintended and accidental beneficiaries of the International Bill of Rights. The section examines the conditions that spurred the conception of the South African human rights movement before the adoption of the UDHR and demonstrates that a South African human rights movement existed before the UDHR. The third section focusses on two principal instruments adopted by the African National Congress (the ANC) - the vanguard of the liberation movement in South Africa - namely, the African Bill of Rights (1923) and the African's Claims in South Africa (1943). The two documents are essential to the discussion as they illustrate South African aspirations for a Bill of Rights before the adoption of the UDHR, the International Covenant on Civil and Political Rights (the ICCPR) and the International Covenant on Economic, Social, Religious and Cultural Rights (the ICESCR).

The fourth section analyses the local human rights movement after the adoption of the UDHR and covers the Defiance Campaign Against Unjust

6 See SAHO 1996 https://www.sahistory.org.za/dated-event/mandela-signs-saconstitution-law.

7 See Klug Constituting Democracy 1-2; Venter 2010 SAJHR 45-65; Fombad "Evolution of Modern African Constitutions" 13.

8 See Ngcukaitobi The Land is Ours 1-2.

$9 \quad$ See Greenberg et al "Introduction" xix. 
Laws (1952), the Freedom Charter (1955) and the Guidelines for a Democratic South Africa (1989). The section also illustrates that despite the momentum of the international human rights movement in the last half of the $20^{\text {th }}$ Century, South Africans continued to charter the path for a Bill of Rights independent of the global human rights movement. The fifth section focusses on the formal adoption of the Bill of Rights in both the transitional and final Constitutions to show the influence of the International Bill of Rights at that stage. ${ }^{10}$ The fifth section also illustrates the application of the International Bill of Rights under the South African Constitution.

\section{The global human rights movement in the South African context}

This section discusses the birth of the international human rights movement in the context of South African realities to reiterate the view expressed by Mutua that the global human rights movement was conceived as a response to the atrocities of Europeans against Europeans, not as a means for the end of colonialism, which subjugated Africans to brutal colonial regimes. ${ }^{11}$ In the context of this work, the human rights movement refers "to that collection of norms, processes, and institutions that traces its immediate ancestry to the Universal Declaration of Human Rights."12 The international human rights movement encompasses persons and organisations that contributed to the commitment of the United Nations to adopt the rights embodied in the principal instruments which comprise the International Bill of Rights, namely the UDHR, the ICCPR and the ICESCR. ${ }^{13}$ The Charter of the United Nations, ${ }^{14}$ adopted at the end of World War II, did not specify the universal human rights to which it alluded. Hence, the United Nations adopted the UDHR to catalogue inherent human rights. ${ }^{15}$ However, the UDHR was a mere declaration ratified by the General Assembly of the United Nations but not signed by member states. ${ }^{16}$ As such, the UDHR is

10 The transitional Constitution was the Constitution of the Republic of South Africa Act 200 of 1993.

11 See Mutua 1997 Harv Hum Rts $J 63$ on the birth of the international human rights movement as a response to "the abominations of World War II". Jayawickrama Judicial Application of Human Rights Law 24 also argues that the terrors of German Nazis and the birth of the United Nations in the middle of the $20^{\text {th }}$ Century prompted the birth of international human rights law.

12 Mutua 2001 Harv Int'l LJ. Given scholarly consensus that the international human rights commenced at the end of World War II, the argument by Neier International Human Rights Movement 3 that the Soweto riots of 1976 in South Africa contributed to the birth of the international human rights movement cannot be sustained.

13 Neier International Human Rights Movement 2.

14 Charter of the United Nations (1945).

15 Jayawickrama Judicial Application of Human Rights Law 25.

16 Hinds 1985 Crime and Social Justice 6. 
not an international treaty per se. ${ }^{17}$ Notwithstanding, the UDHR is binding under customary international law. ${ }^{18}$ Presently, the UDHR is the gold standard for the protection of human rights. ${ }^{19}$ The UDHR is the cornerstone of international human rights law and an embodiment of the global spirit for the universality of moral standards for human dignity and other inalienable rights. ${ }^{20}$

Whereas the drafting of the UDHR commenced in $1947,{ }^{21}$ the adoption of the UDHR in 1948 coincided with the formal adoption of apartheid in South Africa. ${ }^{22}$ Apartheid was a policy of the National Party which codified racial discrimination and repression, under-development and the brutal exploitation of Africans for the benefit of whites in South Africa. ${ }^{23}$ Apartheid "formalise[d] and systematise[d], with often vindictive cruelty, existing racial subordination, humiliation and exclusion." 24 South Africa's adoption of apartheid in the same year as the UDHR illustrates that the UDHR had nothing to do with calls for the amelioration of the conditions of peoples living under colonial rule. ${ }^{25}$ South Africa refused to participate in the ratification of the UDHR since the UDHR contrasts with everything which apartheid represented.

Nonetheless, the adoption of the UDHR was insignificant for Africans in South Africa. Africans had no representation in the adoption of the UDHR. ${ }^{26}$ Their plight under a brutal regime was neither mentioned nor condemned in the text of the UDHR. The omission to incorporate the liberation of Africans living under colonial regimes in the UDHR implies that the drafters did not intend to address colonial subjugation and that they did not consider decolonisation an issue of sufficient international concern to warrant inclusion in such an important instrument. ${ }^{27}$

\footnotetext{
Jayawickrama Judicial Application of Human Rights Law 29. Jayawickrama Judicial Application of Human Rights Law 6.

Roberts Contentious History of the International Bill of Rights 1.

Roberts Contentious History of the International Bill of Rights 264, 266.

Leher Dignity and Human Rights 21.

22 Kuwonu 2019 https://www.un.org/africarenewal/magazine/december-2018-march2019/africa\%E2\%80\%99s-freedom-struggles-and-universal-declaration-humanrights.

23 The literature on the racially discriminative and exploitative nature of apartheid is vast. See, for instance (in general), Clark and Worger South Africa.

24 Hinds 1985 Crime and Social Justice 5.

25 According to Heyns and Viljoen 2001 Hum Rts Q 483, the assessment of the success or failure of international human rights instruments should be evaluated on their impact on human in the domestic environment.

26 Ruta v Minister of Home Affairs 20193 BCLR 383 (CC) para 25.

27 See Mutua 2001 Harv Int'l LJ 211 for a full analysis.
} 
On face value, it is ironic that the UDHR, which proclaims that "[a]II humans are born free and equal in dignity and rights"28 and that "[e]veryone is entitled to all the rights and freedoms", 29 does not contain a single sentence on the liberation of subjugated peoples. The omission leaves one wondering whether terms such as "all humans" and "everyone" in the UDHR could have been intended to include Africans at all. It appears that South Africans were incidental, accidental and unintended beneficiaries of the UDHR supposing that one assumes that the UDHR had any immediate benefits for Africans. Given that the drafters of the UDHR were the founders of the international human rights movement, ${ }^{30}$ it is conceivable that the human rights movement did not intend the International Bill of Rights to benefit South Africans and other Africans. The ICCPR and the ICESCR, the two instruments which reinforce the nonbinding UDHR, ${ }^{31}$ should also be understood in the context in which world powers adopted the UDHR. ${ }^{32}$

\section{The conception of the local human rights movement in South Africa}

This section discusses the genesis of the local human rights movement in South Africa to show that contrary to the claims of the international human rights movement, South Africans who lived under colonial rule conceived human rights with the formation of the South African Native National Congress (now the ANC) in 1912. ${ }^{33}$ The section proves that the South African human rights movement was born for two purposes - liberation from colonial rule and the attainment of a democratic system of government based on the free will of the governed. The context in which the formation of the ANC conceived South African human rights is critical to the proper understanding of the roots of the Bill of Rights, particularly given that the history of South Africa is punctuated with colonisation and apartheid.

The arrival of Jan van Riebeek and his crew on the shores of modern-day Cape Town in 1652 marked the beginning of colonial encroachment on South Africa. Feuds between Dutch and British settlers led to the formation of two independent Boer Republics in the Orange Free State and the Transvaal. In both republics, "colonisation remained wedded to brutal

\footnotetext{
Article 1 of the UDHR.

Article 2 of the UDHR.

Mutua "Transformation of Africa" 906.

Roberts Contentious History of the International Bill of Rights 2.

See Jayawickrama Judicial Application of Human Rights Law 44 on the conception of the ICCPR and the ICESCR in 1952.

33 For the reader's convenience, this article uses "ANC" to refer to the liberation movement in its formative years when it was the South African Native National Congress and when it began formally pronouncing itself as the ANC.
} 
exploitation of the conquered population."34 The establishment of the Union of South Africa in 1910 cemented the exploitation of Africans by whites, leading African lawyers under the ANC to demand a Bill of Rights. ${ }^{35}$ It is disheartening that whereas there is ample literature on gross colonial and apartheid violations in South Africa, ${ }^{36}$ contemporary legal and historical accounts of pre-1994 give scant attention to the role played by African intellectuals in South Africa's long journey to constitutional democracy. ${ }^{37}$ Scholarly neglect of the contributions of Africans to the liberation struggle undermines efforts towards an understanding and appreciation of the role of the local human rights movement towards constitutionalism in South Africa. ${ }^{38}$ Sachs $\mathrm{J}$ relates the scholarly neglect to the machinations of the apartheid regime as follows:

\begin{abstract}
Apartheid had distorted [the contribution of Africans towards freedom], subordinating each and every action to its racist context, suppressing all that was noble and highlighting all that was ugly. The ideals of democracy and freedom are presented as white ideals, the assumption being that blacks are only interested in a full stomach, not in questions of freedom. Daily life refutes this notion. It is the anti-apartheid struggle that has kept democracy alive in South Africa. ${ }^{39}$
\end{abstract}

Africans formed the ANC in 1912 to defend their rights and to liberate themselves from a colonial government which relegated them to "hewers of wood and drawers of water".40 African lawyers committed to constitutionalism and reiterated their fidelity to the law even in the face of the most institutionally exploitative political, economic and social environment. The resistance of Africans against apartheid was thus a struggle for liberation, for the rule of law, for justice and for the attainment of authentic and inclusive democracy. African lawyers believed that "injustice could only be fought with justice, illegality with legality and colonialism with constitutionalism." 41 Whereas several African organisations contributed to the end of apartheid and the adoption of the current

34 Meierhenrich Legacies of Law 89. The irony is not lost that in the middle of the $19^{\text {th }}$ Century, the drafters of the Orange Free State Constitution, 1854 copied whole sections from the Constitution of the United States of America, 1787 not because they admired liberal democracy but "as an attempt to legitimise the boer settlers' preferences for slavery and oppressive race discrimination laws" - Loveland By Due Process of Law? 49.

35 Asmal, Chidester and Lubisi Legacy of Freedom 47-51.

36 Some of the principal works are Clark and Worger South Africa; Dyzenhaus Judging the Judges; Dugard Human Rights and the South African Legal Order and Madala 2000 NC J Int'l L \& Com Reg 743-765.

37 Ngcukaitobi The Land is Ours 5.

38 See Fowkes Building the Constitution 3.

39 Sachs We, the People 25.

40 See Venter 2010 SAJHR 47.

41 Ngcukaitobi The Land is Ours 74. 
constitutional order, the ANC emerged as the most potent. However, the ANC struggled to be "the big tent in which the diverse opposition elements could rally towards a collective end."42 In this article, the account of the efforts of Africans against the apartheid system mostly focusses on the work of the ANC. The analysis does not intend (and should not be understood) to glorify the ANC or recognise its work as being more important than that of other organisations.

It is also essential to highlight that although the struggle against apartheid was a struggle of Africans against a white system of government, some whites contributed to the struggle and sacrificed as much, if not more, than many Africans. Venter points out that in the academia, Professors Ben Beinart, John Dugard and Johan van Vyver (among others) contributed to the human rights discourse in the 1960s and 1970s. ${ }^{43}$ Mutua $^{44}$ also recognises the contribution of whites and the cooperation of whites and Africans in the fight against apartheid but cynically questions the overemphasis on the contribution of whites (the do-gooders) to the liberation struggle. Mutua's cynicism should be understood within the context that some whites saw the approach of the end of apartheid and strategically positioned themselves for a new South Africa. Mutua gives the example of Arthur Chaskalson, whom President Mandela appointed as the first Judge President of the Constitutional Court.

Another suitable example for Mutua's argument would be Richard Goldstone. In the biography The Trials of Richard Goldstone, Terris ${ }^{45}$ presents Goldstone $\mathrm{J}$ as an apartheid judge whose foresight enabled him to change gears with such alacrity as to secure a seat on the first bench of the Constitutional Court. Like many judicial officers who served the apartheid regime, Goldstone $\mathrm{J}$ contributed to the validation and legitimation of unjust laws and government actions through judicial decisions. ${ }^{46}$ Notwithstanding, the genuine intentions and contributions of people like Sachs $\mathrm{J}$ to the fight against apartheid cannot be questioned. Sachs $\mathrm{J}$ fled to exile and lost his hand and eye in a targeted bombing by apartheid forces. ${ }^{47}$

Notwithstanding contestations on the contributions of Africans and whites to

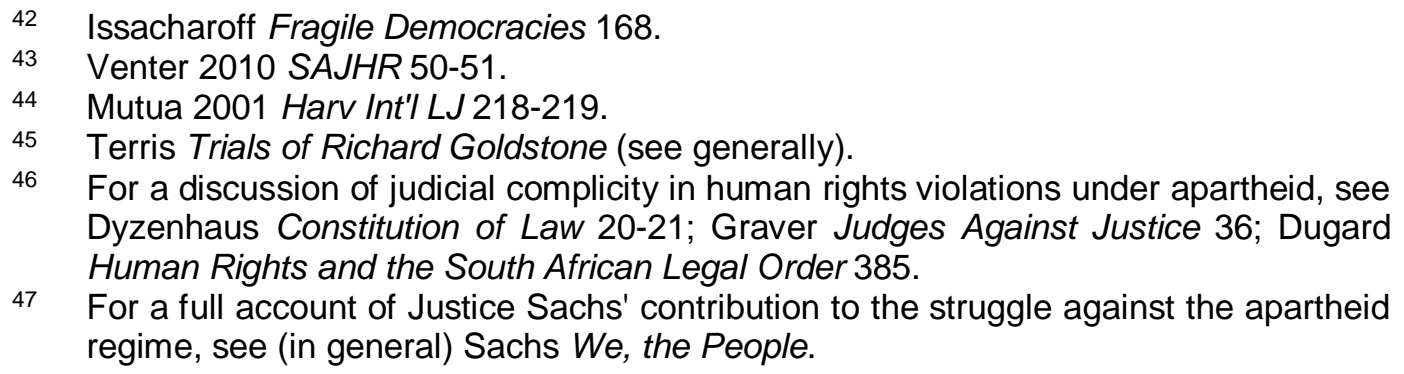

47 For a full account of Justice Sachs' contribution to the struggle against the apartheid regime, see (in general) Sachs We, the People. 
the adoption of the Bill of Rights, the formation of the ANC marked the birth of a local human rights movement in South Africa. The ANC was composed of African intellectuals who opposed the colonial system and advocated the liberation of Africans and respect for human rights. As such, the ANC was both a liberation movement and a human rights movement. In 1923 an ANC conference in Bloemfontein adopted the African Bill of Rights. ${ }^{48}$ The central themes in the African Bill of Rights were the demand for land, freedom, the equality of all citizens before the law, and justice. ${ }^{49}$ Although the colonial administration treated Africans as subhuman and therefore felt justified in denying them access to justice and the freedoms which it accorded to whites, the ANC never adopted a resolution to exclude whites from the enjoyment of the rights which it advocated for Africans. ${ }^{50}$ In its eyes, all South Africans were equal (and continue to be), regardless of their gender, race and origin. The 1923 African Bill of Rights called for the representation of Africans in the legislature and agitated for no taxation of Africans without representation in Parliament. ${ }^{51}$

Two decades after the adoption of the African Bill of Rights, African intellectuals drew another Bill of Rights, contained in a document entitled the "African's Claims in South Africa", which was adopted by the ANC on 16 December 1943. ${ }^{52}$ The African's Claims emanated from deliberations on the accommodation of Africans in the post-World War II era. ${ }^{53}$ The document was a response to the Atlantic Charter, a precursor to the Charter of the United Nations and the UDHR. Hence, the African's Claims is also known as the Atlantic Charter from the African's Point of View. ${ }^{54}$ The ANC intended to present the African's Claims at a peace conference which would follow World War II. ${ }^{55}$ The African's Claims originated from the idea that the eradication of threats to humanity, peace and racial goodwill required a universal application of the Atlantic Charter. At the heart of the African's Claims lay the demand for universal adult suffrage and the end of racial discrimination. ${ }^{56}$ The expansive Bill of Rights in the African's Claims included the rights to full citizenship, equality in the courts, justice, representation in all forms of governance, freedom of trade and occupation,

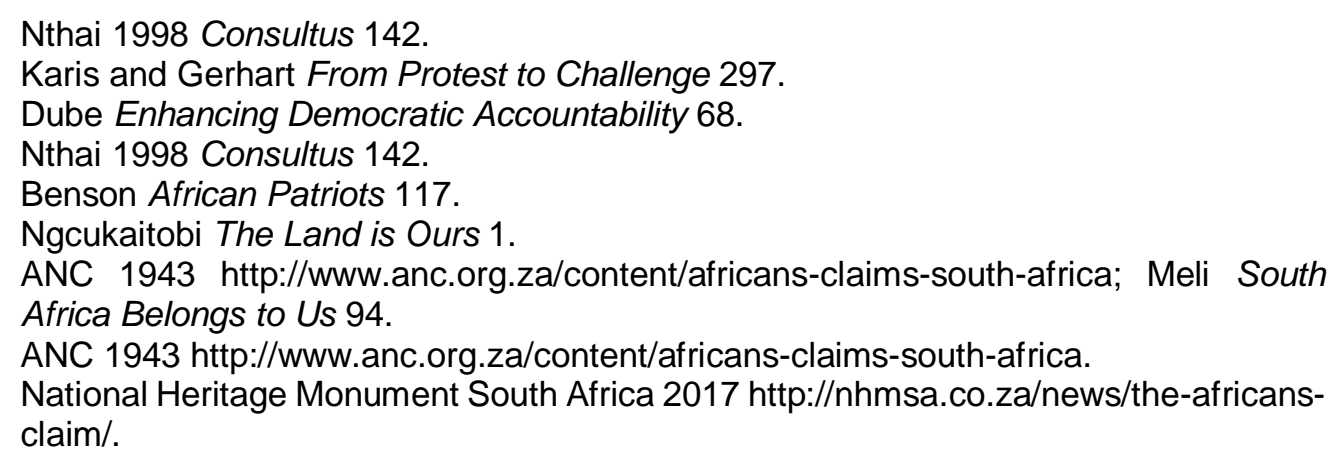


equality in the workplace, adequate medical and health facilities, and nondiscrimination in all spheres of South African life. ${ }^{57}$

In the current South African Constitution, the founding provisions express the resolutions of the African's Claims. ${ }^{58}$ Therefore, it is clear that the ANC committed to the founding constitutional values four decades before the adoption of the transitional Constitution. Although the Preamble and section 1 of the current Constitution do not mention the African's Claims, they are an acknowledgement and expression of its values for constitutionalism and human rights. ${ }^{59}$ However, the 1923 and 1943 Bill of Rights did not yield fruits for the ANC. The atrocities of World War II firmly gripped the West, leading to the adoption of the Charter of the United Nations, the UDHR, the ICCPR and the ICESCR.

\section{The South African human rights movement after the adoption of the UDHR}

This section discusses the local human rights movement after the adoption of the UDHR to show that the momentum for liberation and human rights in South Africa continued independently from international events which followed World War II. The section seeks to prove that despite the adoption of the UDHR, South Africans continued to charter a human rights course without the influence of the international human rights movement. In 1952 it was clear to the ANC that peaceful overtures to the government and proposals for constitutional change would not achieve the desired outcomes for freedom, justice and democratic representation for Africans. The government had enacted more repressive laws against Africans. ${ }^{60}$ Instead of using "petitions, deputations, meetings and polite persuasions [to bring about the repeal of discriminatory and unjust laws, it was necessary to shift to] mass actions, boycotts and strikes." 61 Before embarking on the Defiance Campaign Against Unjust Laws, the ANC gave the government an ultimatum to repeal the repressive laws by 6 April 1952. The office of the Prime Minister responded to the ultimatum and questioned the audacity and fraudulent attempt by the ANC to speak on behalf of Africans. The

57 For a discussion of the content of the 1943 Bill of Rights, see Nthai 1998 Consultus 143 and Ngcukaitobi The Land is Ours 6. Also see Benson African Patriots 117.

58 Ngcukaitobi The Land is Ours 1.

59 For a further discussion of the significance of the African's Claims for modern constitutionalism, see Sachs We, the People 12-13.

60 Some of the statutes were the Natives (Abolition of Passes and Co-ordination of Documents) Act 67 of 1952; Group Areas Act 41 of 1950; Suppression of Communism Act 44 of 1950; Separate Representation of Voters Act 46 of 1951 and the Bantu Authorities Act 68 of 1951.

61 Cameron Justice 29-30. 
government also threatened to unleash violence, despite the commitment of the ANC to conduct a peaceful campaign. ${ }^{62}$ The Defiance Campaign was a testimony that if a people cannot bring their government to account through peaceful and democratic processes, they are likely to resort to radical measures. In contemporary times, the relevance of the Defiance Campaign to the discourse on constitutionalism and human rights is found in some of its defining features, particularly the unifying struggle chants Afrika and Mayibuye. ${ }^{63}$

The apartheid government responded to the Defiance Campaign with force and detentions. Mandela, then a young lawyer, led the Defiance and was subsequently arrested and convicted under section $11(\mathrm{~b})$ of the Suppression of Communism Act, ${ }^{64}$ which criminalised all acts committed to bring social and political change. Although the statute was disguised as a pushback against the spread of communism, it was mostly intended to suppress activities of Africans against unjust and suppressive legislation. When the Law Society moved an application in the Supreme Court to strike Mandela off the roll of attorneys because of his conviction on criminal charges, the court was not convinced and argued that Mandela's actions in leading the Defiance were driven by a desire to serve Africans and to bring about the repeal of unjust apartheid laws. ${ }^{65}$ The court held that Mandela's conduct was not dishonest, and neither were his actions disgraceful, nor dishonourable, to warrant removal from the roll of attorneys. However, the Defiance Campaign did not yield tangible results for the ANC. Hence, in 1955 the ANC adopted the Freedom Charter as a vision for the realisation of the aims of the Defiance Campaign.

A Congress of the People adopted the Freedom Charter in Kliptown. ${ }^{66}$ The conception of the Freedom Charter was momentous for Africans and their struggle towards a free and just society. ${ }^{67}$ The Preamble to the Freedom

62 Benson African Patriots 175-176.

63 See the analysis by Mogoeng CJ in United Democratic Movement $v$ Speaker of the National Assembly 20178 BCLR 1061 (CC) para 7. For an account of struggle songs during the Defiance Campaign, see SAHO 2017 http://www.sahistory.org.za/topic/defiance-campaign-1952. Struggle songs often evoke emotions and spark litigation in contemporary South Africa. For some of the cases, see Afri-Forum v Malema 20114 All SA 293 (EqC) and Duncanmec (Pty) Ltd v Gaylard 201811 BCLR 1335 (CC).

64 Suppression of Communism Act 44 of 1950.

65 Incorporated Law Society, Transvaal v Mandela 19543 SA 102 (T) 108D-E.

66 Davis 2003 ICON 181-195.

67 Ngcukaitobi The Land is Ours 6. 
Charter starts with the declaration "We, the People of South Africa", ${ }^{68}$ as an indication of the representative and inclusiveness of the delegates who adopted it. It goes further to declare "that only a democratic state, based on the will of all the people, can secure to all their birthright without distinction of colour, race, sex or belief." The Freedom Charter contains ten sections conceived on the ideals of a just and free South Africa which recognises the equality of everyone before the law. ${ }^{69}$ The Freedom Charter also gives practical relevance, within the context of oppression and unjust laws, to the ideals of democracy, human rights and freedoms. ${ }^{70}$ Perhaps the most critical provision in the Freedom Charter is that "The People shall govern". The Freedom Charter was a recognition of the illegitimacy of the apartheid regime and the need to establish a constitutional democracy.

The Freedom Charter was a vision of a South Africa designed in many ways to be the opposite of that of the apartheid regime. Although framed in quasipolitical language, the Freedom Charter contains provisions of a contemporary Bill of Rights. ${ }^{71}$ The ideals of the Freedom Charter lived throughout the reign of the apartheid regime and find expression in the Constitutional Guidelines for a Democratic South Africa. ${ }^{72}$ Today, the Preamble to the Constitution and the founding provisions restate core aspects of the Freedom Charter, such as "South Africa belongs to all who live in it, black and white." The founding provisions in section 1 of the Constitution (freedom, equality, human dignity and political rights) espouse all the ideals of the Freedom Charter. However, the apartheid regime and its supporters viewed the Freedom Charter as a socialist expression and an anti-capitalist instrument. These negative interpretations were motivated by the reality that under apartheid the en masse oppression of Africans was entangled with capitalist exploitation. ${ }^{73}$

The commitments to constitutionalism previously expressed in the African's Claims found their way into the Constitutional Guidelines for a Democratic South Africa, adopted by the ANC in 1989. ${ }^{74}$ The ANC believed that racial domination and inequality perpetrated over the previous centuries had to be

68 For a copy of the Freedom Charter, see the Historical Papers Research Archive 2013 http://www.historicalpapers.wits.ac.za/inventories/inv_pdfo/AD1137/AD1137-Ea6-1-

001-jpeg.pdf.

69 See the commentary by Sachs We, the People 21.

70 Corder and Davis 1989 SALJ 634-635.

71 Davis 2003 ICON 183.

72 ANC 1989 https://www.sahistory.org.za/sites/default/files/DC/pam19890000.026.021. 000/pam19890000.026.021.000.pdf.

73 See Hudson 1986 Transformation 8-9.

74 ANC 1989 https://www.sahistory.org.za/sites/default/files/DC/pam19890000.026.021. 000/pam19890000.026.021.000.pdf. 
overcome with corrective action grounded in constitutional law. ${ }^{75}$ The Constitutional Guidelines committed the ANC to constitutional limitations on the exercise of public power. ${ }^{76}$ Admittedly, the liberation movement also understood the need for a written and supreme constitution to regulate the exercise of power in an orderly, organised and predictable manner. The ANC also appreciated constitutionalism as an essential guarantee for the exercise of public power in a democratic state which holds the government accountable and protects rights through an independent judiciary. ${ }^{77}$

The adoption of the Constitutional Guidelines affirmed to the international community that the ANC and its members were human rights proponents and constitutionalists. The document cast doubt on the apartheid narrative that the liberation movement was no more than a group of power-hungry communist thugs. ${ }^{78}$ Notably, the Constitutional Guidelines was the brainchild of ANC President Oliver Tambo. As Sachs J observes, the Constitution contains the DNA of Oliver Tambo, to whom constitutionalism was important for the constitution-making process and his vision to secure the rights of all the people of South Africa. ${ }^{79}$ His aim was "to convert the Freedom Charter into an operational document and become the cornerstone of our country's new constitutional order." 80 What made it more critical for Tambo to push for the protection and entrenchment of human rights, among other limitations on government authority, was his status as an exile. Banned from his country, Tambo had no abstract concept of the need to protect human rights. His situation was painfully real. ${ }^{81}$

\section{The birth of the South African Bill of Rights}

Although the analyses in the preceding sections of this article show that South Africans conceived the local human rights movement independently of and without the influence of the global human rights movement, this section recognises and discusses the (limited) contribution of the international human rights movement to the birth of the Bill of Rights. The aim of this section is to illustrate that whereas South Africans conceived and gestated the Bill of Rights without the involvement of the international

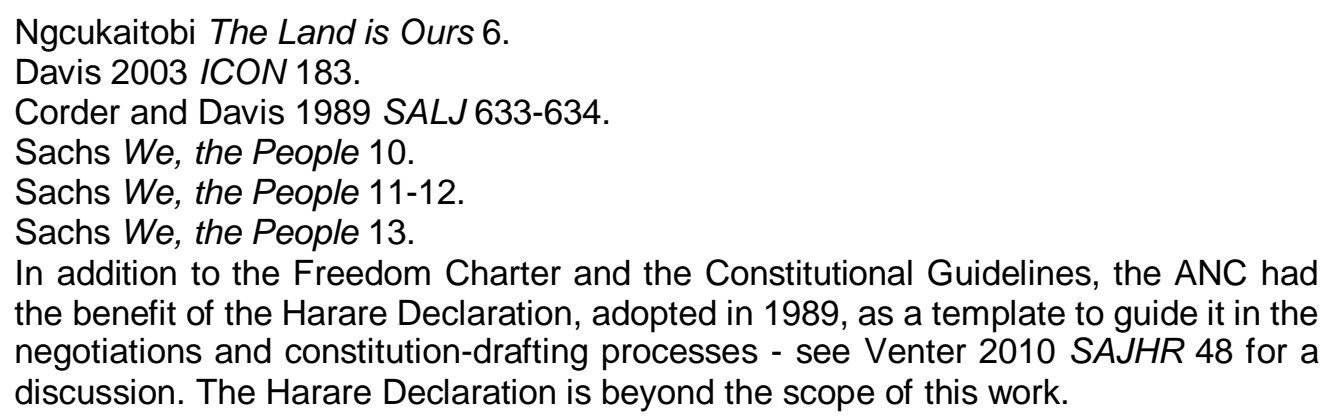
the benefit of the Harare Declaration, adopted in 1989, as a template to guide it in the negotiations and constitution-drafting processes - see Venter 2010 SAJHR 48 for a discussion. The Harare Declaration is beyond the scope of this work. 
human rights movement, the global human rights movement contributed to the birth of the Bill of Rights. If one uses a metaphor which depicts the Bill of Rights as a child, South Africans are the parents of the child, whereas the international human rights movement could be taken for the midwife who facilitates the birth of the child. No matter how immense her role, a midwife has no legal basis for claiming maternity of the child.

The analysis in this section begins with the observation that despite initial indifference at colonialism and apartheid, the United Nations condemned apartheid. Between 1952 and 1990 the General Assembly of the United Nations criticised apartheid for conflicting with articles 55 and 56 of the Charter of the United Nations. ${ }^{82}$ In 1973 the United Nations criminalised apartheid with the International Convention on the Suppression and Punishment of the Crime of Apartheid (the Apartheid Convention). ${ }^{83}$ The Convention classified apartheid as a crime against humanity and was a stinging rebuke of the discriminatory racial policy in South Africa. ${ }^{84}$ The atrocities of the apartheid regime prompted the international community to monitor the situation in South Africa. The Soweto Uprising of 1976, in which apartheid forces gunned down youths, attracted international condemnation and sanctions. ${ }^{85}$

At the end of the 1980s the apartheid regime accepted that the cost of maintaining apartheid was unsustainable. ${ }^{86}$ The regime faced serious domestic and global challenges to its legitimacy. ${ }^{87}$ The international community was in solidarity with Africans and had suspended and expelled South Africa from all international bodies. ${ }^{88}$ Economic sanctions and an arms embargo imposed by the United Nations Security Council had caused high inflation and ballooned the sovereign debt until the country was on the verge of bankruptcy. Economic and political challenges left the government with no choice but to lean towards negotiation with its exiled political opponents. Hence, in 1987 the regime began secret negotiations with the ANC and other political groups. The collapse of the Soviet Union and the fall of the Iron Curtain catalysed the process of internal engagement in South Africa. For the ANC, the collapse of the Soviet Union ended a

82 Dugard 2008 http://legal.un.org/avl/pdf/ha/cspca/cspca_e.pdf.

83 International Convention on the Suppression and $\bar{P}$ unishment of the Crime of Apartheid (1973) (the Apartheid Convention).

84 Article 1 of the Apartheid Convention.

85 See Neier International Human Rights Movement 16.

86 Gibson and Gouws Overcoming Intolerance in South Africa 16; Van der Schyff Judicial Review of Legislation 39.

87 Van der Schyff Judicial Review of Legislation 39. See also Cornell Law and Revolution in South Africa 1; Gibson and Gouws Overcoming Intolerance in South Africa 17.

88 Moseneke My Own Liberator 233, 258. 
relationship with a valuable ally. For the apartheid regime, the collapse of the Soviet Union took away the "last remaining international card ... of the Western anticommunist alliance." 89

At the beginning of the last decade of the $20^{\text {th }}$ Century, the apartheid regime unbanned its political opponents to create a political climate conducive to engagement. It also commenced formal negotiations at the Convention for a Democratic South Africa (CODESA). ${ }^{90}$ However, the CODESA negotiations collapsed, with the result that another negotiation process, the Multi-Party Negotiation Process (MPNP), was established. In the middle of 1993 the negotiating parties announced that they had reached consensus on the first inclusive elections and that they had agreed on a two-stage transition to constitutional democracy. ${ }^{91}$ The parties agreed that the Constitutional Assembly, ${ }^{92}$ composed of members of a democratically elected legislature, would draft a Constitution based on pre-agreed principles espoused in Schedule 4 of the transitional Constitution. ${ }^{93}$ In addition to commitments to a diverse, united, equal and free South Africa, the negotiating parties agreed that there should be a supreme, written Constitution in which all South Africans enjoyed universal rights and freedoms protected in international law. ${ }^{94}$ It is in these commitments that one appreciates the birth of the Bill of Rights at the MPNP. Whereas African intellectuals conceived the African Bill of Rights many decades earlier, the negotiation process gave birth to a justiciable Bill of Rights. ${ }^{95}$

However, not all South African scholars agree on the genesis of the local human rights movement. Venter argues that the adoption of liberal constitutionalism (which introduced an entrenched and justiciable Bill of Rights) was an "unintended consequence" because none of the negotiating parties were "'natural' proponents of late $20^{\text {th }}$-century constitutionalism". ${ }^{96}$ Venter argues that: ${ }^{97}$

The ANC did have a documentary record of propounding human rights in its campaigns to mobilise international support for its cause, but in the preceding

89 Issacharoff Fragile Democracies 167.

90 For a discussion of the prearrangements for the formal negotiations, see Issacharoff Fragile Democracies 167.

91 For a full discussion of the negotiations and the transition phase, see Klug "Public Participation and the Death Penalty" 259-264.

92 Section 68(1) of the transitional Constitution created the Constitutional Assembly, composed of the National Assembly and the Senate sitting jointly for the purpose of constitution-making.

93 Section 71 of the transitional Constitution.

94 Cameron Justice 79.

95 Cameron Justice 180.

96 Venter 2010 SAJHR 49.

97 Venter 2010 SAJHR 49-50. 
decades it was supported materially and doctrinally by the governments with the poorest human rights records of the time. Under the influence of the Soviet bloc and the enthusiastic promotion of socialism within the ANC by the South African Communist Party, much of the thinking in the organisation favoured a centralised state, the redistribution of wealth and a people's revolution. ... On the other side of the table the government was one operating within the tradition of a constitutional framework entrenched in the bedrock of parliamentary sovereignty, in principle hostile to the notion of an enforceable Bill of Rights and with a recent record of suppressing fundamental freedoms and autocratic utilisation of legislation and executive fiat for the purposes of achieving political goals.

Venter's argument shows that the ANC was in a catch-22 situation. It could seek and receive support from communist regimes with poor human rights records and risk soiling its image as a liberation movement committed to liberal democracy, or it could try (with guaranteed futility) to obtain military, financial, logistical and other support from Western liberal states which brought colonisation to Africa. With no resources, the ANC was bound to accept aid from any state, even if doing so meant seeking and accepting help from some of the alleged worst human rights violators such as the Soviet Union. Ironically, the drafters of the UDHR, who started the international human rights movement, did not provide support to the South African liberation movement. The irony is not lost that the Western human rights movement wants to take credit for a Bill of Rights brought about partly through the support of communist regimes with ugly human rights records when it did not itself give support to the liberation movement.

The apartheid regime was notorious for "codified repression"98 and the brutal violations of human rights..$^{99}$ However, it is not surprising that it pushed for the adoption of an entrenched and justiciable Bill of Rights backed by the Constitutional Court, since ${ }^{100}$

Threatened political elites, eager to preserve their current status beyond future majoritarian elections, press for the constitutionalization of rights (as they understand them) to preserve their policy preferences: 'judicial empowerment through the constitutionalization of rights and the establishment of judicial review may provide an efficient institutional means by which political elites can insulate their increasingly challenged policy preferences against popular pressure, especially when majoritarian decision-making procedures are not operating to their advantage.'

Therefore, one can argue that the apartheid regime supported the adoption of a Bill of Rights for its own ends, not for the broader concerns of all South Africans. Notwithstanding different perspectives on the correct source and motives of the local human rights movement, the International Bill of Rights

\footnotetext{
$98 \quad$ See Moseneke My Own Liberator 209.

99 Venter 2010 SAJHR 50.

100 Lemieux and Watkins Judicial Review and Contemporary Democratic Theory 24.
} 
had some influence (albeit limited) on the text of the South African Bill of Rights. Whereas it is not the intention of this article to juxtapose the wording and substantive content of the South African Bill of Rights with that of the International Bill of Rights, one example illustrates the influence of one on the wording of the other. There is a correlation between the founding provisions of the UDHR and the South African Bill of Rights. Both are founded on the inherence of human dignity and equality. Whereas the Preamble to the UDHR recognises the inherence of human dignity and equality, the South African Bill of Rights is a cornerstone of democracy founded inter alia on human dignity. ${ }^{101}$ The similarity in the texts of some parts of the UDHR and the Bill of Rights shows that the drafting process of the latter was influenced by the language of the former.

The Bill of Rights protects all the rights in the UDHR, the ICCPR and the ICESCR. The human rights jurisprudence developed by the courts in South Africa is firmly anchored in international human rights law, although there are fewer than expected cases in which the courts have alluded to the instruments which comprise the International Bill of Rights. ${ }^{102}$ Despite the seemingly limited judicial appetite to invoke the International Bill of Rights in judgments, courts have a constitutional obligation to consider international law and foreign law when interpreting the Bill of Rights. ${ }^{103}$ Section 323 of the Constitution further binds South Africa to customary international law, which includes the International Bill of Rights. ${ }^{104}$ The provision illustrates the tremendous influence of the global human rights movement on the drafting of the Bill of Rights in South Africa.

\section{Conclusion}

Whereas the efforts of the international human rights movement were seminal in the development of international human rights law, as espoused in the International Bill of Rights, their influence in colonial and apartheid South Africa was insignificant. African intellectuals conceived the local human rights movement for a democratic South Africa independently from,

101 Section $7(1)$ of the Constitution.

102 See, for instance, Claasen v Minister of Justice and Constitutional Development 2010 2 SACR 451 (WCC) paras 16, 24, 36 and 37; $S$ v Dodo 20015 BCLR 423 (CC) paras 46-47; South African Human Rights Commission v Qwelane; Qwelane v Minister for Justice and Correctional Services 20174 All SA 234 (GJ) para 45; Ruta v Minister of Home Affairs 20193 BCLR 383 (CC) paras 25-26; Rahube v Rahube 20191 BCLR 125 (CC) para 1.

103 Section 39(1) of the Constitution.

104 See Jayawickrama Judicial Application of Human Rights Law 6 on the UDHR as a binding aspect of customary international law. Also see article 38 of the Statute of the International Court of Justice (1946) on the sources of international law. 
and before, the adoption of the UDHR. Consequently, the South African Bill of Rights is not a product of adoption of, assimilation of or borrowing from the International Bill of Rights. South Africans own the Bill of Rights. The fact that the international human rights movement played a role in the drafting of the Bill of Rights does not distract from the reality that South Africans conceptualised a human rights approach to colonisation.

In this work, the focus is on the work of the ANC because the liberation movement dominated the apartheid struggle and presently governs South Africa. The ANC opposed exploitative and illegitimate colonial and apartheid systems by actively pushing for the overhaul of the political and economic system to insulate the people of South Africa from state abuse and to protect rights. The ANC adopted the first Bill of Rights in 1923 and the African's Claims in South Africa in 1943 as antidotes for colonisation and apartheid. After the adoption of the UDHR and its sister instruments, the South African human rights movement gained momentum without the influence of the global human rights movement. The Defiance Campaign Against Unjust Laws (1952), the Freedom Charter (1955) and the Constitutional Guidelines for a Democratic South Africa (1989) illustrate the independent and unique growth of the South African human rights movement. The documents highlight the contribution of Africans to a human rights culture and reiterate that human rights are not an alien concept to the people of South Africa.

Although Africans conceived the notion of local human rights in South Africa, they were not alone after the first half of the $20^{\text {th }}$ Century. Some whites contributed immensely to the struggle for liberation and human rights, some more than others, albeit with different intentions at different times. Given the contribution of both Africans and whites to the struggle against apartheid, South Africans are collectively responsible for the adoption of the Bill of Rights in its present state, regardless of their satisfaction or lack thereof with it. Whether or not the Bill of Rights is adequate for the correction of the injustices of colonialism and apartheid is a question which should be addressed from the premise that contrary to the claims of the international human rights movement, the Bill of Rights is a product of the collective efforts of progressive South Africans. Conclusively, the South African Bill of Rights was neither adopted nor borrowed from the International Bill of Rights. 


\section{Bibliography}

\section{Literature}

Asmal, Chidester and Lubisi Legacy of Freedom

Asmal K, Chidester D and Lubisi C (eds) Legacy of Freedom: The ANC's Human Rights Tradition (Jonathan Ball Johannesburg 2005)

Benson African Patriots

Benson M The African Patriots: The Story of the African National Congress of South Africa (Faber and Faber London 1963)

Cameron Justice

Cameron E Justice: A Personal Account (Media24 Boeke Cape Town 2014)

Clark and Worger South Africa

Clark NL and Worger WH South Africa: The Rise and Fall of Apartheid $3^{\text {rd }}$ ed (Routledge New York 2016)

Corder and Davis 1989 SALJ

Corder $\mathrm{H}$ and Davis D "The Constitutional Guidelines of the African National Congress: A Preliminary Assessment" 1989 SALJ 633-647

Cornell Law and Revolution in South Africa

Cornell D Law and Revolution in South Africa: Ubuntu, Dignity and the Struggle for Constitutional Transformation (Fordham University Press New York 2014)

Davis 2003 ICON

Davis DM "Constitutional Borrowing: The Influence of Legal Culture and Local History in the Reconstitution of Comparative Influence: The South African Experience" 2003 ICON 181-195

Dube Enhancing Democratic Accountability

Dube F Enhancing Democratic Accountability through Constitutionalism in South Africa (LLD thesis North-West University 2019)

Dugard Human Rights and the South African Legal Order Dugard J Human Rights and the South African Legal Order (Princeton University Press Princeton 1978)

Dyzenhaus Judging the Judges

Dyzenhaus D Judging the Judges, Judging Ourselves: Truth, Reconciliation and the Apartheid Legal Order (Hart Oxford 1998) 
Dyzenhaus Constitution of Law

Dyzenhaus D The Constitution of Law: Legality in a Time of Emergency (Cambridge University Press New York 2006)

Fombad "Evolution of Modern African Constitutions"

Fombad CM "The Evolution of Modern African Constitutions: A Retrospective Perspective" in Fombad CM (ed) Separation of Powers in African Constitutionalism (Oxford University Press Oxford 2016) 13-57

Fowkes Building the Constitution

Fowkes J Building the Constitution: The Practice of Constitutional Interpretation in Post-Apartheid South Africa (Cambridge University Press Cambridge 2016)

Gibson and Gouws Overcoming Intolerance in South Africa

Gibson $\mathrm{JL}$ and Gouws A Overcoming Intolerance in South Africa: Experiments in Democratic Persuasion (Cambridge University Press Cambridge 2003)

Graver Judges Against Justice

Graver HP Judges Against Justice: On Judges When the Rule of Law is Under Attack (Springer Berlin 2015)

Greenberg et al "Introduction"

Greenberg D et al "Introduction" in Greenberg D et al (eds) Constitutionalism and Democracy: Transitions in the Contemporary World (Oxford University Press New York 1993) xv-xxiii

Heyns and Viljoen 2001 Hum Rts $Q$

Heyns $C$ and Viljoen $F$ "The Impact of the United Nations Human Rights Treaties on the Domestic Level" 2001 Hum Rts Q 483-535

Hinds 1985 Crime and Social Justice

Hinds LS "Apartheid in South Africa and the Universal Declaration of Human Rights" 1985 Crime and Social Justice 5-43

Hudson 1986 Transformation

Hudson $\mathrm{P}$ "The Freedom Charter and the Theory of National Democratic Revolution" 1986 Transformation 6-38

Issacharoff Fragile Democracies

Issacharoff S Fragile Democracies: Contested Power in the Era of Constitutional Courts (Cambridge University Press New York 2015) 
Jayawickrama Judicial Application of Human Rights Law

Jayawickrama N The Judicial Application of Human Rights Law: National, Regional and International Jurisprudence (Cambridge University Press Cambridge 2002)

Karis and Gerhart From Protest to Challenge

Karis T and Gerhart GM From Protest to Challenge (Indiana University Press Indiana 1972)

Klug Constituting Democracy

Klug H Constituting Democracy: Law Globalism, and South Africa's Political Reconstruction (Cambridge University Press Cambridge 2000)

Klug "Public Participation and the Death Penalty"

Klug $\mathrm{H}$ "Public Participation and the Death Penalty in South Africa's Constitution-Making Process" in Abbiate T, Böckenförde M and Federico V (eds) Public Participation in African Constitutionalism (Routledge London 2018) 258-270

Leher Dignity and Human Rights

Leher SP Dignity and Human Rights: Language Philosophy and Social Realizations (Routledge New York 2018)

Lemieux and Watkins Judicial Review and Contemporary Democratic Theory

Lemieux S and Watkins DJ Judicial Review and Contemporary Democratic Theory: Power, Domination and the Courts (Routledge New York 2018)

Loveland By Due Process of Law?

Loveland I By Due Process of Law? Racial Discrimination and the Right to Vote in South Africa 1855-1960 (Hart Oxford 1999)

Madala 2000 NC J Int'l L \& Com Reg

Madala TH "Rule Under Apartheid and the Fledgling Democracy in PostApartheid South Africa: The Role of the Judiciary" 2000 NC J Int'l L \& Com Reg 743-765

Meierhenrich Legacies of Law

Meierhenrich J The Legacies of Law: Long-Run Consequences of Legal Development in South Africa, 1652-2000 (Cambridge University Press Cambridge 2008) 
Meli South Africa Belongs to Us

Meli F South Africa Belongs to Us: A History of the ANC (Zimbabwe Publishing House Harare 1988)

Moseneke My Own Liberator

Moseneke D My Own Liberator: A Memoir (Picador Africa Johannesburg 2016)

Mutua 1997 Harv Hum Rts J

Mutua M "Hope and Despair for a New South Africa: The Limits of Rights Discourse" 1997 Harv Hum Rts J 63-114

Mutua 2001 Harv Int'I LJ

Mutua M "Savages, Victims, and Saviors: The Metaphor of Human Rights" 2001 Harv Int'l LJ 201-245

Mutua "Transformation of Africa"

Mutua M "The Transformation of Africa: A Critique of the Rights Discourse" in Isa FG and De Feiter K (eds) International Human Rights Law in a Global Context (Universidad de Deusto Bilbao 2009) 899-924

Neier International Human Rights Movement

Neier A The International Human Rights Movement: A History (Princeton University Press Princeton 2012)

Ngcukaitobi The Land is Ours

Ngcukaitobi T The Land is Ours: South Africa's First Black Lawyers and the Birth of Constitutionalism (Penguin Random House South Africa Century City 2018)

Nthai 1998 Consultus

Nthai S "A Bill of Rights for South Africa: An Historical Overview" 1998 Consultus 142-143

Roberts Contentious History of the International Bill of Rights

Roberts CN The Contentious History of the International Bill of Rights (Cambridge University Press New York 2015)

Sachs We, the People

Sachs A We, the People: Insights of an Activist Judge (Wits University Press Johannesburg 2016) 
Terris Trials of Richard Goldstone

Terris D The Trials of Richard Goldstone (Rutgers University Press New Brunswick 2019)

Van der Schyff Judicial Review of Legislation

Van der Schyff G Judicial Review of Legislation: A Comparative Study of the United Kingdom, the Netherlands and South Africa (Springer Dordrecht 2010)

Venter 2010 SAJHR

Venter F "Liberal Democracy: The Unintended Consequence. South African Constitution-Writing Propelled by the Winds of Globalisation" 2010 SAJHR 45-65

\section{Case law}

Afri-Forum v Malema 20114 All SA 293 (EqC)

Claasen v Minister of Justice and Constitutional Development 20102 SACR 451 (WCC)

Duncanmec (Pty) Ltd v Gaylard 201811 BCLR 1335 (CC)

Incorporated Law Society, Transvaal v Mandela 19543 SA 102 (T)

Rahube v Rahube 20191 BCLR 125 (CC)

Ruta v Minister of Home Affairs 20193 BCLR 383 (CC)

S v Dodo 20015 BCLR 423 (CC)

South African Human Rights Commission v Qwelane; Qwelane v Minister for Justice and Correctional Services 20174 All SA 234 (GJ)

United Democratic Movement v Speaker of the National Assembly 20178 BCLR 1061 (CC)

\section{Legislation}

Bantu Authorities Act 68 of 1951

Constitution of the Republic of South Africa Act 200 of 1993

Constitution of the Republic of South Africa, 1996 
Constitution of the United States of America, 1787

Group Areas Act 41 of 1950

Natives (Abolition of Passes and Co-ordination of Documents) Act 67 of 1952

Orange Free State Constitution, 1854

Separate Representation of Voters Act 46 of 1951

Suppression of Communism Act 44 of 1950

International instruments

Charter of the United Nations (1945)

International Convention on the Suppression and Punishment of the Crime of Apartheid (1973)

International Covenant on Civil and Political Rights (1966)

International Covenant on Economic, Social and Cultural Rights (1966)

Statute of the International Court of Justice (1946)

Universal Declaration of Human Rights (1948)

\section{Internet sources}

ANC 1943 http://www.anc.org.za/content/africans-claims-south-africa

ANC 1943 Africa's Claims in South Africa
http://www.anc.org.za/content/africans-claims-south-africa accessed 9 March 2018

ANC $\quad 1989 \quad$ https://www.sahistory.org.za/sites/default/files/DC/pam 19890000.026.021.000/pam19890000.026.021.000.pdf

ANC 1989 Constitutional Guidelines for a Democratic South Africa https://www.sahistory.org.za/sites/default/files/DC/pam19890000.026.021. 000/pam19890000.026.021.000.pdf accessed 2 December 2018

Dugard 2008 http://legal.un.org/avl/pdf/ha/cspca/cspca_e.pdf Dugard J 2008 Convention on the Suppression and Punishment of the Crime of Apartheid http://legal.un.org/avl/pdf/ha/cspca/cspca_e.pdf accessed 10 October 2019 
Historical Papers Research Archive 2013 http://www.historicalpapers.wits.ac.za/inventories/inv_pdfo/AD1137/AD113 7-Ea6-1-001-jpeg.pdf

Historical Papers Research Archive 2013 The Freedom Charter http://www.historicalpapers.wits.ac.za/inventories/inv_pdfo/AD1137/AD113 7-Ea6-1-001-jpeg.pdf accessed 20 January 2020

Kuwonu 2019 https://www.un.org/africarenewal/magazine/december-2018march-2019/africa\%E2\%80\%99s-freedom-struggles-and-universaldeclaration-human-rights

Kuwonu F 2019 Africa's Freedom Struggles and the Universal Declaration of Human Rights https://www.un.org/africarenewal/magazine/december2018-march-2019/africa\%E2\%80\%99s-freedom-struggles-and-universaldeclaration-human-rights accessed 29 January 2018

National Heritage Monument South Africa 2017 http://nhmsa.co.za/news/the-africans-claim/

National Heritage Monument South Africa 2017 The African's Claims http://nhmsa.co.za/news/the-africans-claim/ accessed 4 March 2018

SAHO 1996 https://www.sahistory.org.za/dated-event/mandela-signs-saconstitution-law

South African History Online 1996 Mandela Signs SA Constitution into Law https://www.sahistory.org.za/dated-event/mandela-signs-sa-constitutionlaw accessed 2 October 2019

SAHO 2017 http://www.sahistory.org.za/topic/defiance-campaign-1952

South African History Online 2017 Defiance Campaign 1952 http://www.sahistory.org.za/topic/defiance-campaign-1952 accessed 8 December 2017

\section{List of Abbreviations}

ANC

CODESA

Harv Hum Rts J

Harv Int'I LJ

Hum Rts Q

ICCPR

ICESRC
African National Congress

Convention for a Democratic South Africa Harvard Human Rights Journal Harvard International Law Journal Human Rights Quarterly International Covenant on Civil and Political Rights

International Covenant on Economic, Social, Religious and Cultural Rights 
ICON

MPNP

NC J Int'l L \& Com Reg

SAHO

SAJHR

SALJ

UDHR
International Journal of Constitutional Law

Multi-Party Negotiation Process

North Carolina Journal of International Law and Commercial Regulation

South African History Online

South African Journal on Human Rights

South African Law Journal

Universal Declaration of Human Rights 